\title{
Saint Martin (French Part)
}

National Cancer Institute

\section{Source}

National Cancer Institute. Saint Martin (French Part). NCI Thesaurus. Code C83610.

A country comprising the northern portion of an island in the Caribbean sea, between

Anguilla and Saint Barthelemy. 